\title{
Paper-chromatographic Studies on Change in Gibberellins during Seed Development and Germination in Pharbitis Nil
}

\author{
by Yutaka MuraKAMI*
}

\section{Received December 13, 1960}

The occurrence of gibberellin-like substances in higher plants has been observed by several investigators including the author with various plant extracts ${ }^{1}$. Also it has been known that immature seeds contain these substances of much higher concentrations than those in mature seeds of the same species ${ }^{1}$. In a previous paper ${ }^{2}$ ) the author has reported that the paper-chromatographic behaviors of active materials from several kinds of immature seeds differ from those of the chemically known gibberellins. The work here described was done to see whether or not the paperchromatographic pattern of gibberellin activity remained unchanged during seed development and germination. The use of the Japanese morning-glory as plant material is very convenient for this purpose, since its seeds are extremely abundant in gibberellin-like substances $\left.{ }^{3}, 4\right)$.

\section{Materials and Methods}

Seeds of Pharbitis Nil (Japanese morning-glory) were sown in pots and grown in a greenhouse at about $25^{\circ}$. From these plants, fruit samples were taken for the first time on the 6th day after anthesis and samplings were continued until the maturity of the seeds at the specified intervals. Each fruit usually contains 4 seeds and so 4 seeds or seedlings were used for the measurements of gibberellins.

For studies of seedlings the seeds were germinated and permitted to develop on a moist filter paper at about $20^{\circ}$ in the dark room. Four seedlings were taken at the specified intervals.

Four seeds or seedlings, immediately after harvest, were weighed, ground with a pestle and mortar, extracted with $50 \mathrm{ml}$. of $70 \%$ acetone for 20 hours at room temperature, and then filtered. The residue was extracted once more in a similar manner for 3 hours. The combined filtrate was evaporated to dryness under reduced pressure. The resulting residue was dissolved in a small volume of $70 \%$ acetone and directly used for paper chromatography to separate the various active substances present in the extracts.

A sheet of Toyo No. 50 filter paper was used throughout the work. Chromatograms of the extracts were developed by the ascending method in the dark at about $27^{\circ}$, until the solvent front reached $30 \mathrm{~cm}$. from the starting line. The solvent used was the mixture of iso-propanol/ammonia/water $(10: 1: 1 \mathrm{~V} / \mathrm{V})$. The developed chromatogram was dried, folded lengthwise $2 \mathrm{~cm}$. in width, and cut transversely at $2 \mathrm{~cm}$. intervals. Each segment was then placed in beakers $2 \mathrm{~cm}$. in diameter and $7 \mathrm{~cm}$. in height containing $1.5 \mathrm{ml}$. of water. The author's rice seedling method was used to detect gibberellin activity. Five rice seedlings "Aichi-Asahi", whose coleoptiles attained about $1 \mathrm{~mm}$., were planted in each beaker and allowed to grow under ordinary

* National Institute of Agricultural Sciences, Nishigahara, Kita-Ku, Tokyo, Japan. 


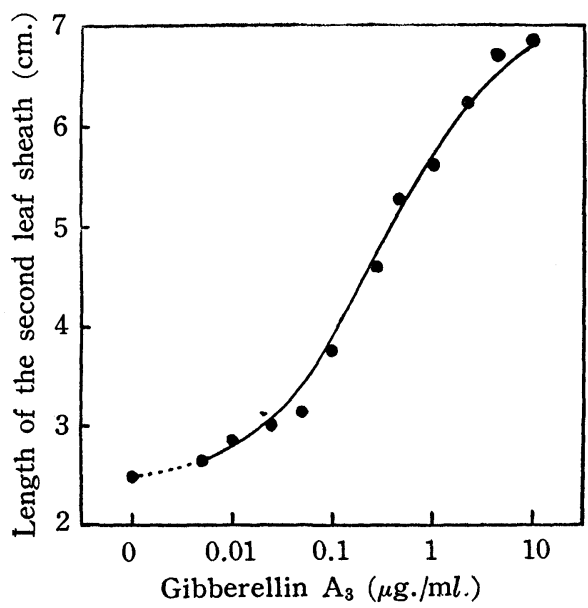

Fig. 1. Response of the second leaf sheath of rice seedling to gibberellin $A_{3}$.
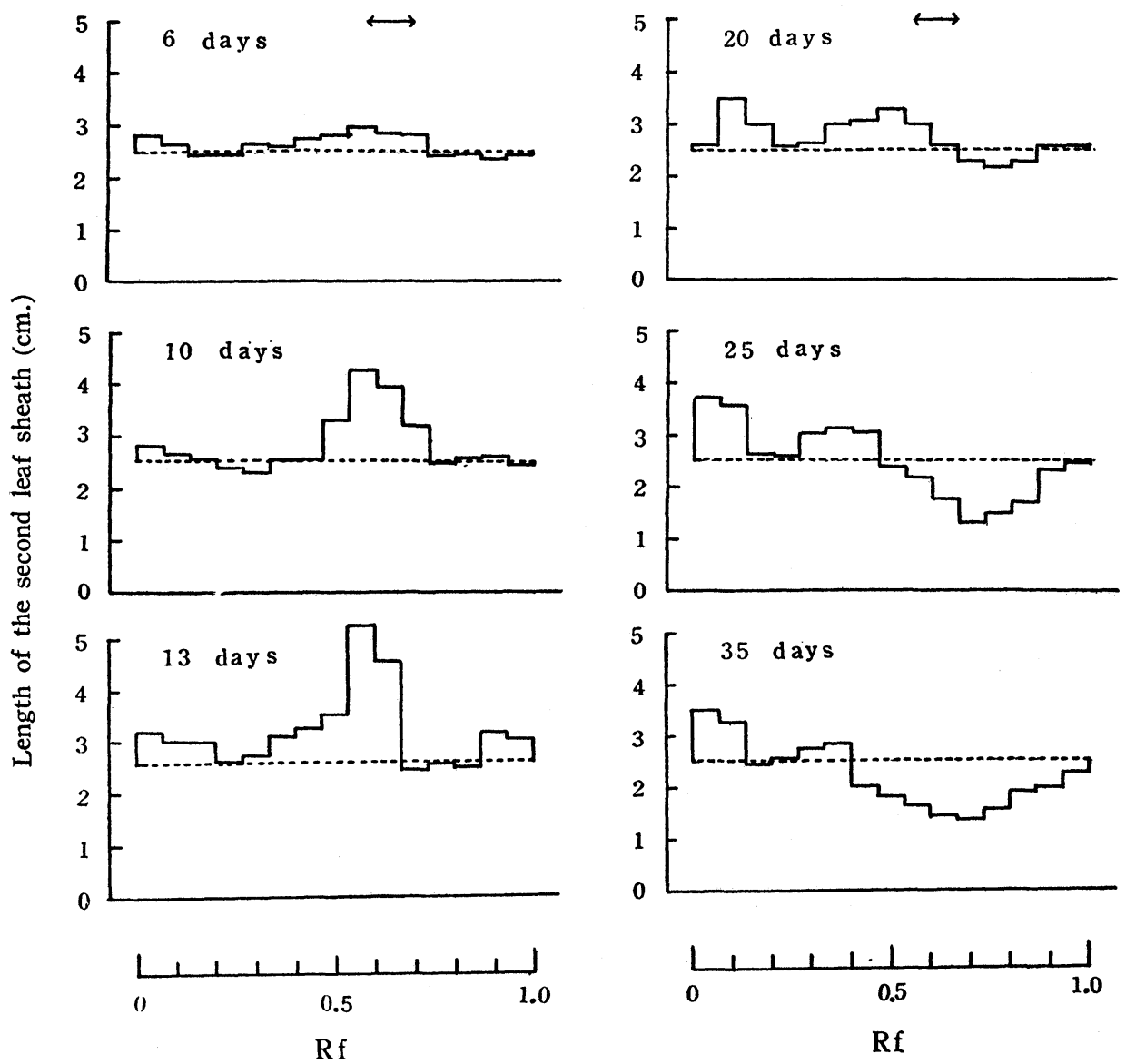

Fig. 2. Histograms showing gibberellin activity of acetone extracts of 4 seeds of Pharbitis Nil from anthesis to maturity after paper-chromatographic development with ammoniacal iso-propanol. Days on the hisotgrams represent the time after anthesis. Broken lines denote water controls. Arrows at the top of the histograms indicate the position of gibberellin $A_{3}$. 
daylight conditions at about $30^{\circ}$. They were supplied with $0.5 \mathrm{ml}$. water every other day. The length of the second leaf sheath was measured after 7 days when the third leaf blade was beginning to unfold from the second leaf sheath. The results were expressed in the mean length per beaker. A typical growth response of the second leaf sheath of rice seedlings to gibberellin $A_{3}$ is shown in Fig. 1.

\section{Results and Discussion}

The histograms of gibberellin activity obtained with acetone extracts of the seeds of Pharbitis Nil at different stages of maturity are shown in Fig. 2. This figure is based on the experiment in which the bioassay was made with rice seedlings. Therefore the term gibberellin is used for compounds having the property of causing growth promotion of the second leaf sheath of rice seedlings. The horizontal broken lines in the figure represent the growth of controls so that leaf sheath elongations greater than this represent the presence of gibberellin activity.

Changes in the level of gibberellin during seed maturity, which were determined by the methods indicated in Figs. 1 and 2, are presented in Fig. 3 . In this figure the changes in fresh weight of seeds are shown. The results, which are evident from Fig. 3, show that under the conditions of present experiments the amount of gibberellin rises rapidly after anthesis to 13th day, but thereafter it falls markedly. The amount extracted from the immature seeds on 13th day after anthesis corresponds to $1.4 \mu \mathrm{g}$. of gibberellin $\mathrm{A}_{3}$ per 4 seeds. When the seeds were fully ripened, it decreased to only $1 / 6$ of what it was on the 13th day after anthesis. On the 13th day after anthesis the embryo in the seed was as small as $2 \mathrm{~mm}$. long but on the 20th day it was as large as the seed $10 \mathrm{~mm}$. long. The maximum growth of the seeds, expressed in fresh weight increase, appeared subsequent to the time when the amount gibberellin reached the highest level. These results are in agreement with those of the earlier report of Mitchell

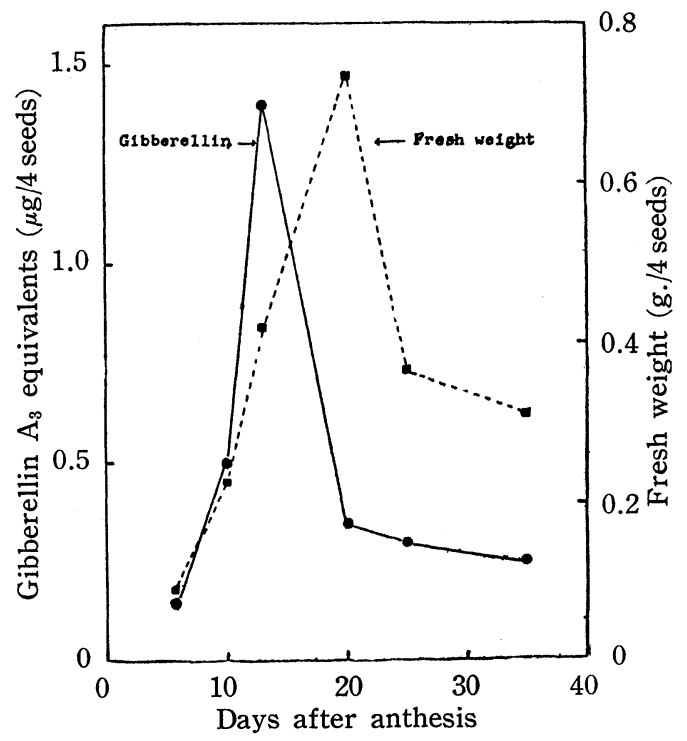

Fig. 3. Changes in gibberellin concentration and fresh weight in Pharbitis Nil seeds from anthesis to maturity. et al..$^{5}$ ) and also of Corcoran $^{6}$ ) with Echinocystis macrocarpa, Lupinus succulentus, and Phaseolus vulgaris.

The occurrence not only of quantitative but also of qualitative changes in gibberellin during the development of Pharbitis Nil seeds can be seen on the histograms in Fig. 2. Until 13th day after anthesis the pattern of growth-promoting activity remained almost unchanged qualitatively. The growth-promoting zone of $\mathrm{Rf} 0.55-0.7$ contained the major growth substance which promoted a remarkable elongation of rice seedlings and reached a maximum on the 13th day after anthesis. Since this promoting zone occurs at the $\mathrm{Rf}$ similar to that of gibberellins $A_{1}, A_{2}, A_{3}$ and $A_{4}$, one of which, gibberellin $A_{1}$, has been isolated from higher plants ${ }^{7,8,9}$, the growth 
promotion in this zone is considered to be due to the presence of gibberellin $A_{1}, A_{2}$, $A_{3}$ or/and $A_{4}$. Some indications of small activity were also found in other zones of the chromatograms.

On the 20th day after anthesis the level of gibberellin in the Rf region of 0.55 0.7 suddenly decreased, but two other promoting zones, which have smaller $\mathrm{Rf}$ values, 0.0-0.2 and 0.3-0.5, respectively, appeared. Moreover, a large inhibiting zone appeared in the region between $\mathrm{Rf} 0.6$ and 0.9 . And the pattern of growth substances remained unchanged until seed maturity.

It was found from preliminary experiments that the inhibiting substances are able to be extracted from an aqueous solution with chloroform at $\mathrm{pH} 2.5$ but under the same conditions gibberellin $\mathrm{A}$ is not extractable. Then the syrup obtained from 4 mature seeds as described above, was taken up with $30 \mathrm{ml}$. water, acidified to pH 2.5 with phosphoric acid and extracted two times with the equal volume of chloroform. This chloroform extract was discarded. After the $\mathrm{pH}$ of the aqueous fraction was adjusted to 7.0 with $10 \%$ potassium hydroxide, the solution was evaporated to a small volume under reduced pressure, separated on paper chromatogram

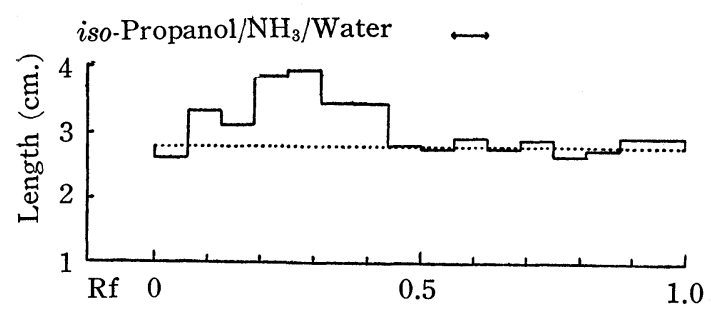

Fig. 4. The histogram showing gibberellin activity of acetone extracts of 4 mature seeds of Pharbitis Nil after removing inhibiting substances with chloroform. with ammoniacal $i$ so-propanol, and bioassayed by the rice seedling method. The result is given in Fig. 4. On the chromatogram in Fig. 4 no promoting zone corresponding to gibberellin $\mathrm{A}_{3}$ occurred. Of course, as already reported in a previous paper ${ }^{3}$ ), the promoting zone corresponding to gibberellin $A_{3}$ could be clearly detected in the extract when more than 10 mature seeds of Pharbitis Nil were used. The disappearance of growth promotion at the starting line of the chromatogram is attributable to the inhibition of rice seedlings by the high concentration of salts which was derived from neutralizing the eluate.

Since impurities in the extracts cause variation in both the $\mathrm{Rf}$ and the tailing of the active substance on chromatograms, it seemed necessary to examine further the chromatographic behavior of these active substances in the region of $\operatorname{Rf} 0.0$ 0.5. Then 40 Pharbitis Nil seeds at later stages of development were extracted with $70 \%$ acetone and the extract was chromatographed on a sheet of paper with ammoniacal iso-propanol as in the preceding experiment. The zone corresponding to $\mathrm{Rf} 0.0-0.5$ was eluted with boiling $100 \mathrm{ml}$. of $50 \%$ ethanol three times, the eluate dried, taken up into a small amount of water, and chromatographed ascendingly with

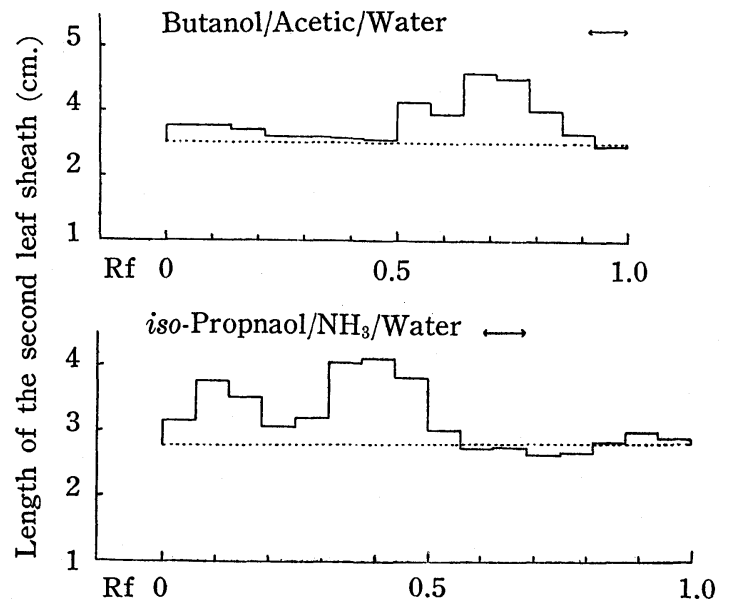

Fig. 5. Histograms showing gibberellin activity of acetone extracts of mature Pharbitis Nil seeds.

Details are described in the text. 
$n$-butanol/glacial acetic acid/water $(4: 1: 2 \mathrm{~V} / \mathrm{V})$ at $27^{\circ}$. After the chromatogram was divided lengthwise into three strips, one of them was cut into 14 equal sections according to the $\mathrm{Rf}$ values and bioassyed by the rice seedling method. The result is shown in Fig. 5. A broad growth-promoting zone was found at $\operatorname{Rf} 0.5-0.85$. Gibberellin $\mathrm{A}_{3}$ runs with the solvent front under the same conditions.

From the remaining strips the zone between $\mathrm{Rf} 0.5$ and $\mathrm{Rf} 0.85$ was excised, reextracted with boiling $50 \%$ ethanol, and the extract again paper-chromotographed with ammoniacal isopropanol, and bioassayed as above. It was found that the promoting activity was reproduced in the zones of $\mathrm{Rf} 0.0-0.2$ and $\mathrm{Rf} 0.3-0.5$ (Fig. 5). From these results it is confirmed that Pharbitis Nil seeds contain new gibberellins whose paper-chromatographic behavior is distinguished from that of the chemically known gibberellins $A_{1}, A_{2}, A_{3}$ and $A_{4}$. Also none of them is identical with bean factor II or gibberellin $A_{5}$, since bean factor II is reported to run two times as far as gibberellin $A_{3}$ in an ammoniacal $n$-butanol solution $\left.{ }^{9}\right)$.

The pattern of growth substances on the paper chromatogram obtained from the etiolated Pharbitis Nil seedlings is presented in Fig. 6. In the histograms of seedlings the same promoting and inhibiting zones are found as in later stages of seed development: two promoting zones at $\mathrm{Rf} 0.0-0.2$ and $\mathrm{Rf} 0.3-0.5$, and a broad inhibiting zone at $\mathrm{Rf}$ 0.6-0.9. The promoting zone corresponding to gibberellin $\mathrm{A}_{3}$ could not be detected with 4 etiolated seedlings between 2 and 14 days after germination. The level of gibberellin extracted from the etiolated seedlings, which was determined
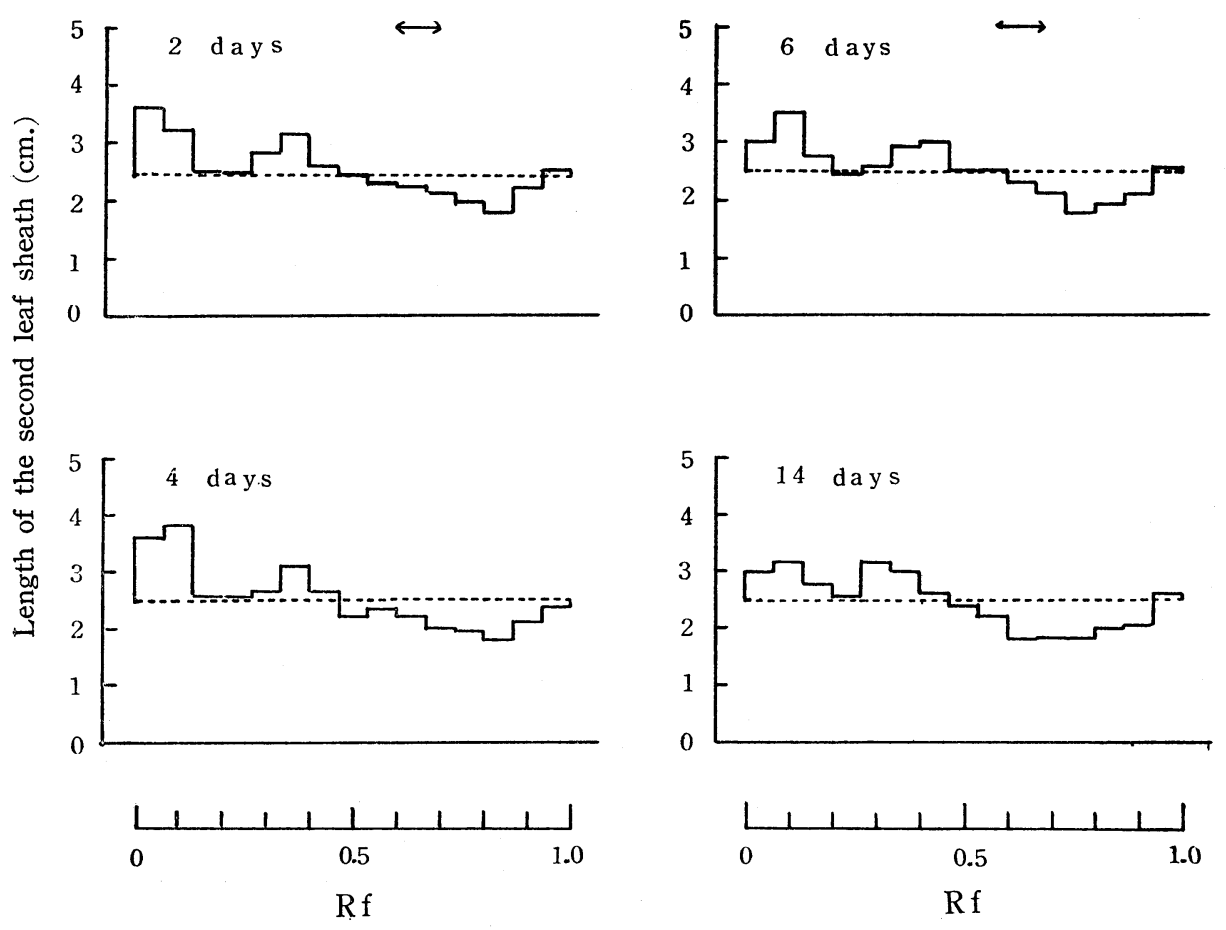

Fig. 6. Histograms showing gibberellin activity of acetone extracts of 4 etiolated seedlings of Pharbitis Nil after paper-chromatographic development with ammoniacal iso-propanol. Days on the histograms represent the time after germination. Further explanations are as in Fig. 2. 
by Figs. 1 and 6, decreased gradually after germination in the dark as shown in Fig. 7. The similar pattern of growth substances was also found with 4 light-grown seedlings at the cotyledon stage (Fig. 8).

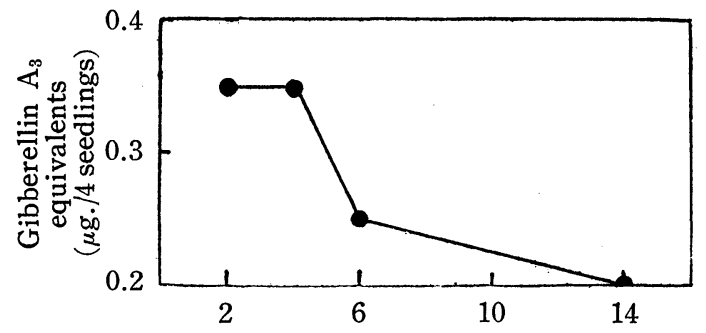

Fig. 7. Changes in gibberellin concentration in etiolated Pharbitis Nil seedlings after germination.

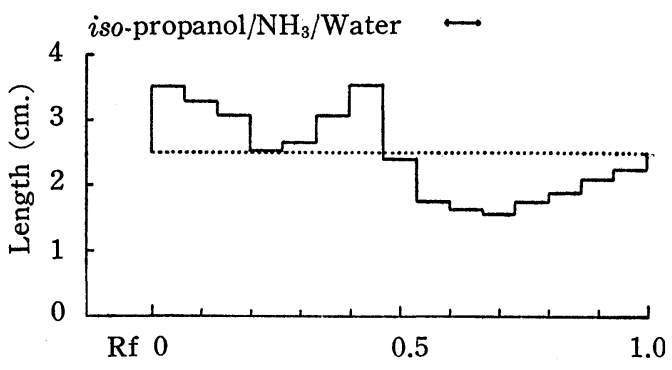

Fig. 8. The histogram showing gibberellin activity of acetone extracts of 4 light-grown seedlings of Pharbitis Nil at the stage having expanded cotyledons.

As already described, the growth-promoting zone corresponding to gibberellin $\mathrm{A}_{3}$ suddenly disappeared at the later stage of seed development and instead two new promoting zones with smaller Rf values occurred. This phenomenon leads the author to suspect that gibberellin $\mathrm{A}_{3}$ or similar compounds might be converted into these new growth-promoting substances in the plant tissue. In order to confirm this hypothesis further experiments are being carried out.

In a previous paper ${ }^{2}$ the author has reported that two zones of gibberellin activity are shown on the chromatograms of immature seeds of leguminous plants and that the activity of the one with $\mathrm{Rf} 0.7$ is attributed to the known gibberellin $\mathrm{A}$, while that of the other with smaller $\mathrm{Rf}$ value of 0.2 is due to a new gibberellin. This smaller $\mathrm{Rf}$ value is practically identical with that of a new gibberellin extracted from Pharbitis Nil seeds. Judging from the results of present experiments, the occurrence of two gibberellin activities in leguminous seeds is thought to depend upon the degree of maturity of the seeds employed.

\section{Summary}

Changes in gibberellins occurring during seed development and germination of Pharbitis Nil were studied by means of paper-chromatography and rice seedling method.

The amount of gibberellin reached its peak on the 13th day after anthesis and thereafter markedly decreased. The maximum amount of extracted gibberellin corresponded to $0.35 \mu \mathrm{g}$. of gibberellin $\mathrm{A}_{3}$ per seed. Gibberellin extracted from etiolated seedlings decreased gradually after germination in the dark.

Three zones of gibberellin activity were found at $\mathrm{Rf} 0.0-0.2$, $\mathrm{Rf} 0.3-0.5$, and $\mathrm{Rf}$ $0.55-0.7$ on the chromatograms developed with the mixture of $i$ so-propanol/ammonia/ water $(10: 1: 1)$. The activity of $\mathrm{Rf} 0.55-0.7$ was attributed to the chemically known gibberellin $A_{1}, A_{2}, A_{3}$, or $A_{4}$.

In initial stages of seed development the gibberellin activity appeared mainly at $\mathrm{Rf} 0.55-0.7$, while in mature seeds and seedlings at smaller $\mathrm{Rf}$ values of $0.0-0.2$ and $0.3-0.5$. 
The author wishes to acknowledge with thanks the encouraging interest of Dr. T. Hayashi.

\section{References}

1) Phinney, B. O., and West, C. A., Ann. Rev. Plant Physiol. 11: 411 (1960). 2) Murakami, Y., Bot. Mag. Tokyo 72: 36 (1959). 3) —, ibid. 72: 438 (1959). 4) Ogawa, Y., and Imamura, S., ibid. 73: 125 (1960). 5) Mitchell, J. W., Skaggs, D. P., and Anderson, W. P., Science. 114: 159 (1951). 6) Corcoran, M. R., Cited by Phinney and West, Ann. Rev. Plant Physiol. 11: 411 (1960). 7) MacMillan, J., and Suter, P. J., Naturwiss. 45: 46 (1958). 8) Kawarada, A., and Sumiki, Y., Bull. Agr. Chem. Soc. Japan 23: 343 (1959). 9) West, C. A., and Phinney, B. O., J. Am. Chem. Soc. 81: 2424 (1959).

\section{摘 要}

村上 浩：アサガオの種子の成熟および発芽過程におけるジベレリンの消長

アサガオの開花から種子の成熟する過程と暗所にて種子を発芽させた場合に括けるジベレリンの消長 を,ペーパークロマトグラフィーにイネ苗試験法を併用して研究した.

アセトン抽出物は, アンモニア性イソプロピルアルコールによる展開で, $\mathrm{A}(\mathrm{Rf}=0-0.2), \mathrm{B}(\mathrm{Rf}=0.3-$ $0.5), \mathrm{C}(\mathrm{Rf}=0.55-0.7)$ の伸長促進部と, $\mathrm{Rf}=0.6-0.9$ の抑制部とにわかれた. C は馬鹿苗病菌の生産する ジベレリンに相当する. 種子の成熟とともに C が減少し， A, B が現われ，同時に抑制物質が出現する.

芽ば光抽出物のペーパークロマトグラムに特ける作用物質のヒストグラムは完熟種子のそれと類似してい る.

成熟過程の種子のジベレリン含量は, 開花後 13 日までは增加し（最高 1 種子当たり $0.35 \mu \mathrm{g}$ のジベレ リン $\mathrm{A}_{3}$ に相当), その後減少する. また発芽の場合, 黄化苗では日の経つにつれてじょじょに減少した. 